\title{
HUBUNGAN TINGKAT PENGETAHUAN DAN SIKAP DENGAN PERILAKU MASYARAKAT DALAM MENGELOLA SAMPAH DI KELURAHAN KURAO PAGANG TAHUN 2018
}

\author{
Afzahul Rahmi ${ }^{1}$, Luthfia $^{21}$ \\ ${ }^{1}$ Program Studi Kesehatan Masyarakat, STIKes Alifah Padang, Indonesia \\ Email:afzahul_rahmi@yahoo.co.id \\ ${ }^{2}$ Program Studi Kesehatan Masyarakat, STIKes Alifah Padang, Indonesia \\ Email :luthfiaskm@gmail.com
}

\begin{abstract}
ABSTRAK
Berdasarkan data dari Dinas Kebersihan Kota Padang pada tahun 2014, jumlah timbulan sampah di Padang mencapai 4839,31 $\mathrm{m}^{3}$ / hari sementara yang dapat diangkut hanya 3353,64 $\mathrm{m}^{3} /$ hari atau 1,636 $\mathrm{m}^{3} /$ hari. Kondisi ini terjadi sebagian karena kemampuan pemerintah Kota Padang untuk pengadaan infrastruktur yang dapat melayani kebutuhan yang ada masih terbatas. Berdasarkan data dari Kantor Sanitasi dan Pertamanan Kota Padang, ditemukan bahwa sumber limbah terbesar di daerah pemukiman di Kota Padang ditemukan di daerah Nanggalo, terutama di Desa Kurao Pagang yang diperkirakan sebesar 8684,8 kg / hari. Penelitian ini bertujuan untuk mengetahui hubungan antara tingkat pengetahuan dan sikap dengan perilaku masyarakat dalam mengelola sampah. Jenis penelitian ini adalah kuantitatif dengan desain penelitian cross sectional. Populasi dalam penelitian ini adalah seluruh keluarga di Desa Kurao Pagang, Kecamatan Nanggalo Padang. Sampel sebanyak 47 orang diambil dengan cara simple random sampling. Pengumpulan data dilakukan melalui wawancara menggunakan pedoman wawancara dalam bentuk kuesioner. Berdasarkan hasil penelitian ditemukan 56,1\% masyarakat memiliki tingkat pengetahuan yang buruk, 53,7\% masyarakat memiliki sikap negatif dan 56,1\% masyarakat memiliki perilaku buruk. Di sana ada hubungan antara tingkat pengetahuan dan sikap dengan perilaku masyarakat dalam mengelola sampah di RW 8 RT 02 Desa Kurao Pagang, Kecamatan Nanggalo Padang pada tahun 2018.
\end{abstract}

Kata kunci: Tingkat pengetahuan, sikap, perilaku

\begin{abstract}
Based on data from the Sanitation Department of Padang City in 2014, the amount of waste generation in Padang reached $4839.31 \mathrm{~m}^{3} /$ day while those that could be transported were only $3353.64 \mathrm{~m}^{3} /$ day or $1,636 \mathrm{~m}^{3} /$ day. This condition occurs partly because the ability of the Padang City government to procure infrastructure that can serve existing needs is still limited. Based on data from the Sanitation and Landscaping Office of Padang City, it was found that the largest source of waste in residential areas in the city of Padang was found in the Nanggalo area, especially in the Kurao Pagang Village which was estimated at $8684.8 \mathrm{~kg} /$ day. This study aims to determine the relationship between the level of knowledge and attitudes with community behavior in managing waste. This type of research was quantitative with a cross sectional study design. The population in this study were all families in Kurao Pagang Village, Nanggalo Padang Subdistrict. Samples totaling 47 people were taken by simple random sampling. Data collection was done through interviews using interview guidelines in the form of questionnaires. Based on the results of the study found $56.1 \%$ of the community had a poor level of knowledge, $53.7 \%$ of the community had a negative attitude and $56.1 \%$ of the community had bad behavior. There where a relationship between the level of knowledge and attitude with the behavior of the community in managing waste in $R W 8 R T$ 02 Kurao Pagang Village, Nanggalo Padang Subdistrict in 2018. It was expected that the Health Office should make efforts to improve the knowledge and attitudes of the community in managing waste.
\end{abstract}

Keywords

: Level of knowledge, attitude, behavior 


\section{PENDAHULUAN}

Pembangunan kesehatan menuju Indonesia sehat ditetapkan enam program pembangunan kesehatan, salah satunya adalah program lingkungan sehat, perilaku sehat dan pemberdayaan masyarakat yang bertujuan untuk mewujudkan mutu lingkungan hidup yang sehat yang mendukung tumbuh kembang anak dan remaja, memenuhi dasar untuk hidup sehat, dan memungkinkan interaksi sosial serta melindungi masyarakat dari ancaman bahaya yang berasal dari lingkungan (Kemenkes RI, 2010).

Masalah sampah di Indonesia merupakan masalah yang rumit karena kurangnya pengertian masyarakat terhadap akibat-akibat yang dapat ditimbulkan oleh sampah, kurangnya biaya pemerintah untuk mengusahakan pembuangan sampah yang baik dan memenuhi syarat. Faktor lain yang menyebabkan permasalahan sampah di Indonesia semakin rumit adalah meningkatnya taraf hidup masyarakat, yang tidak disertai dengan keselarasan pengetahuan tentang persampahan dan juga partisipasi masyarakat yang kurang untuk memelihara kebersihan dan membuang sampah pada tempatnya.

Masalah utama pengelolaan sampah diperkotaan terbatasnya kemampuan pemerintah di daerah dalam menghadapi masalah pengumpulan dan pembuangan sampah yang terus meningkat. Menurut Dirjen Pengelolaan Sampah Limbah dan Bahan Beracun Berbahayapada tahun 2013 jumlah sampah yang diproduksi masyarakat sebanyak 57 ton perhari, pada tahun 2014 meningkat menjadi 62 ton perhari, pada tahun 2015 tersu meningkat menjadi 64 juta ton sampah perhari, pada 2016 ada sekitar 65 juta ton sampah per harinya yang diproduksi masyarakat Indonesia, sedangkan selama tahun 2017 sampah yang diproduksi masyarakat sudah menjadi 70 ton perhari (Kementerian LHK,2017).

Keberadaan sampah yang tidak dikelola dengan baik akan sangat berbahaya bagi kehidupan manusia. Tidak hanya mengganggu keindahan dan kenyamanan, sampah juga bisa menjadi sumber penyakit, menimbulkan banjir, dan merusak alam. Secara umum ada tiga jenis sampah, yaitu organik, anorganik, dan B3 (bahan berbahaya dan beracun). Sampah organik merupakan tempat berkembangnya bakteri, nyamuk, lalat, dan sebagainya yang merupakan sumber penyakit bagi manusia. Sementara itu, sampah anorganik seperti plastik, botol, dan sterofom merupakan salah satu pemicu banjir. Sampah anorganik sangat susah terurai sehingga keberadaannya akan bertahan bertahun-tahun. Tidak hanya akan memenuhi sungai dan memicu banjir, sampah anorganik juga akan merusak kawasan perairan beserta biota yang ada di dalamnya (Indang, 2017).

Dinas Lingkungan Hidup Sumatera Barat (Sumbar) tahun 2017 mencatat volume sampah mencapai 2.392 ton per hari. Jumlah sampah di Kota Padang merupakan yang terbanyak yakni 494 ton per hari. Selain Padang, daerah lainnya yang menjadi penyumbang banyak sampah adalah Kota Bukittinggi 183 ton perhari, Kabupaten Pasaman 162,25 ton, Pasaman Barat 162,18 ton, dan Agam 145,29 ton per hari. Sampah tersebut umumnya masih dibuang ke tempat pembuangan akhir. Namun saatini, pihaknya sedang menggiatkan program bank sampah yang dinilai cukupefektif untuk mengurangi volume sampah.Jumlah bank sampah di Sumbar saat ini sekitar 70, namun yang aktif terdapat 50 unit yang melayani masyarakat menabung sampah.Setelah ditabung nantinya akan dikonversikan ke rupiah, sebagai contoh satu kilogram sampah plastik dari kemasan air minum bernilai sekitar Rp1.000 hingga Rp1.500.Hasil tabungan di bank sampah tersebut, tidak diambil langsung ketika menabung, namun dikumpulkan terlebih dahulu sesuai kebijakan masin-masing bank sampah.

Berdasarkan data Dinas Kebersihan Kota Padang tahun 2014, jumlah timbulan sampah Kota Padang mencapai 4839,31 $\mathrm{m}^{3} /$ hari sedangkan yang dapat terangkut hanya 3353,64 $\mathrm{m}^{3 /}$ hari atau yang tidak terangkut sebanyak $1.636 \mathrm{~m}^{3} /$ hari. Kondisi ini terjadi antara lain karena kemampuan pemerintah Kota Padang untuk pengadaan sarana prasarana yang dapat melayani kebutuhan yang ada masih terbatas.Berdasarkan data Dinas Kebersihan dan Pertamanan Kota Padang, didapatkan sumber sampah di daerah pemukiman yang paling banyak di Kota Padang ditemukan di Daerah Nanggalo khususnya di Kelurahan Kurao Pagang yang diperkirakan sebanyak 8684,8 $\mathrm{kg} /$ hari (Dinas Kebersihan dan Pertamanan Kota Padang, 2014).

Salah satu dampak sampah di Kota Padang yang tidak dikelola dengan baik adalah terjadinya banjir. Karena banyak masyarakat 
membuang sampah di selokan dan sungai, dimana di sepanjang sungai, pemukiman masyarakat sangat padat. Sementara itu, sampah yang terangkut oleh petugas dari Dinas Lingkungan Hidup hanya 60 persen dari total produksi sampah.40 persen lainnya berada di selokan dan sungai. Saat hujan lebat, sampah ini hanyut ke muara dan dihempaskan kembali oleh pasang ke pantai (Dinas Kebersihan dan Pertamanan Kota Padang, 2014).

Penanganan sampah yang komplek dan melibatkan banyak pihak ini memerlukan payung hukum sebagai pegangan. Beberapa produk hukum yang berkaitan dengan sampah antara lain:1) Undang-undang Republik Indonesia Nomor 18 Tahun 2008 Tentang Pengelolaan Sampah. 2) Undang-undang Republik Indonesia Nomor 30 Tahun 2007 Tentang Energi. 3) Peraturan Pemerintah No. 81 Tahun 2012 Tentang Pengelolaan Sampah Rumah Tangga dan Sampah Sejenis Sampah Rumah Tangga. 4) Peraturan Menteri Lingkungan Hidup Republik Indonesia Nomor 13 Tahun 2012 Tentang Pedoman Pelaksanaan Reduce, dan Reuse dan Recycle Melalui Bank Sampah. 5) Peraturan Menteri Lingkungan Hidup Republik Indonesia Nomor 7 Tahun 2011 dan Nomor 1 Tahun 2013 Tentang Pedoman Pelaksanaan Program Adipura, serta perda dari bagai daerah khususnya Kota Padang yaitu Peraturan Daerah (Perda) Kota Padang Nomor 21 tahun 2012 yang mengatur tentang pengelolaan sampah.

Dalam Perda Nomor 21 tahun 2012 pasal 18 dan 19 tentang Pengelolaan Sampah dijelaskan bahwa penyelenggaraan pengelolaan sampah terdiri atas : pembatasan timbunan sampah, pendauran ulang sampah, pemanfaatan kembali sampah, pemilahan sampah, pengumpulan sampah, pengangkutan sampah, pengolahan sampah, pemrosesan sampah, dan pendanaan. Pasal 26 ayat (1) menyebutkan Pemerintah Daerah menyediakan TPS, TPS 3R, TPST, TPA sesuai dengan kebutuhan dengan memperhatikan kepentingan umum. Sedangkan ayat (2) menyebutkan penyediaan TPS, TPS 3R, TPST dan TPA wajib memenuhi persyaratan teknis sistem pengolahan sampah yang aman dan ramah lingkungan sesuai ketentuan peraturan perundang-undangan. Pasal 31 ayat (1), (2), (3), (4) menyebutkan bahwa Lembaga pengelolaan sampah terdiri atas berbagai tingkat diantaranya RT, RW, Kelurahan, dan Kecamatan. Berdasarkan Pasal 61 dijelaskan juga bahwa setiap orang yang dengan sengaja membuang sampah tidak pada tempat yang telah ditentukan dan disediakan, dipidana dengan pidana kurungan paling lama 3 (tiga) bulan atau denda paling banyak Rp. 5000.000 (lima juta rupiah).

\section{METODE PENELITIAN}

Penelitian ini merupakan penelitian analitik dengan menggunakan pendekatan crossectional study yaitu mengetahui hubungan antara variabel independen (pengetahuan dan sikap) dengan variabel dependen (perilaku dalam mengelola sampah) yang diamati dan diukur dalam waktu yang bersamaan. Sampel berjumlah 41 orang dengan teknik pengambilan sampel adalah simple random sampling.

\section{HASIL}

Tabel 1

Distribusi Proporsi Responden Menurut Pengetahun, Sikap dan Perilaku dalam Mengelola Sampah

\begin{tabular}{llll}
\hline Variabel & Kategori & Frekuensi & Persentase \\
\hline Pengetahuan & Kurang Baik & 23 & 43,9 \\
& Baik & 18 & 56,1 \\
Sikap & Negatif & 22 & 53,7 \\
& Positif & 19 & 46,3 \\
Perilaku & Tidak Baik & 23 & 56,1 \\
& Baik & 18 & 43,9 \\
\hline
\end{tabular}


Tabel 1 menunjukkan sebanyak 56,1\% pengetahuan responden adalah kurang baik, sebagian besar memili sikap negatid $(53,7 \%)$ dan perilaku mengelola sampah yang tidak baik sebesar 56,1\%. Tabel 2 menunjukkan responden yang berperilaku tidak baik dala, mengelola sampah lebih banyak yang berpengatahuan kurang baik $(66,7 \%)$ dibandingkan dengan responden yang berpengetahuan baik $(26,1 \%)$ bahwa pengetahuan diketahui berhubungan signifikan dengan perilaku masyarakat dalam dalam mengelola sampah.

Tabel 2

Hubungan Tingkat Pengetahuan dan Sikap dengan Perilaku Masyarakat dalam Mengelola Sampah

\begin{tabular}{llllll}
\hline \multicolumn{1}{c}{ Variabel } & Baik & \multicolumn{3}{c}{$\begin{array}{c}\text { Perilaku } \\
\text { Tidak Baik }\end{array}$} & \multirow{2}{*}{ P value } \\
\cline { 2 - 5 } & $\mathrm{f}$ & $\%$ & $\mathrm{f}$ & $\%$ & \\
\cline { 1 - 4 } $\begin{array}{l}\text { Pengetahuan } \\
\text { Baik }\end{array}$ & 12 & 66,7 & 6 & 33,3 & \multirow{2}{*}{0,023} \\
Kurang baik & 6 & 26,1 & 17 & 73,9 & \\
Sikap & & & & & \\
Positif & 3 & 13,6 & 19 & 86,4 & 0,000 \\
Negatif & 15 & 78,9 & 4 & 21,1 & \\
\hline
\end{tabular}

Tabel 1 menunjukkan bahwa proporsi tingkat pengetahuan responden yang kurang baik lebih banyak yang memiliki perilaku yang tidak baik $(73,9 \%)$ dibandingkan dengan proporsi responden yang memiliki tingkat pengetahuan baik lebih banyak memiliki perilaku yang baik $(66,7 \%)$. Hasil uji statistik Chi-square didapatkan nilai $\mathrm{p}$ value 0,023 $(\mathrm{p}<0,05)$ berarti terdapat hubungan tingkat pengetahuan dengan perilaku masyarakat dalam mengelola sampah. menunjukkan bahwa proporsi sikap responden yang negatif

\section{PEMBAHASAN}

\section{a. Tingkat Pengetahuan}

$\begin{array}{ccr}\text { Berdasarkan } & \text { hasil } & \text { penelitian } \\ \text { didapatkanbahwa } & \text { proporsi } & \text { tingkat }\end{array}$
pengetahuan responden yang kurang baik lebih banyak memiliki perilaku yang tidak baik $(73,9 \%)$. Penelitian ini sama dengan penelitian Sepdianti (2016) tentang perilaku masyarakat dalam pengelolaan sampah menemukan bahwa pengetahuan masyarakat tentang pengelolaan sampah secara umum sudah cukup baik dan sebagian besar bersikap positif.

Dalam mengelola sampah perilaku masyarakat dipengaruhi tingkat pengetahuan dan sikapnya terhadap pengelolaan sampah banyak yang memiliki perilaku yang tidak baik $(86,4 \%)$ dibandingkan dengan proporsi responden yang memiliki sikap yang positif lebih banyak memiliki perilaku yang baik (78,9\%). Hasil uji statistik Chi-square didapatkan nilai $\mathrm{p}$ value $0,000(\mathrm{p}<0,05)$ berarti terdapat hubungan sikap dengan perilaku masyarakat dalam mengelola sampah di RW 8 RT 02 Kelurahan Kurao Pagang Kecamatan Nanggalo Padang tahun 2018.

tersebut. Pengetahuan merupakan domain yang sangat penting untuk terbentuknya tindakan seseorang, pengelolaan sampah berhubungan erat dengan intelektual seseorang, pengetahuan merupakan kemampuan seseorang untuk mengingat sesuatu (ide, fenomena) yang pernah diajarkan. Pengetahuan masyarakat tentang pengelolaan sampah dibangun berdasar kemampuan berpikir sesuai dengan kenyataan yang masyarakat lihat dan temukan di lingkungan sekitar (Notoatmodjo, 2010). 


\section{b. Sikap}

Berdasarkan hasil pengolahan data didapatkan bahwa proporsi sikap responden yang negatif lebih banyak memiliki perilaku yang tidak baik $(86,4 \%)$. Hasil penelitian ini sejalan dengan penelitian Mulasari (2012) tentang hubungan sikap terhadap perilaku masyarakat dalam mengolah sampah di Yogyakarta, menemukan adanya hubungan antara sikap dengan perilaku masyarakat dalam mengolah sampah.

Dalam sikap positif, kecenderungan tindakan adalah mendekati, menyenangi, mengharapkan objek tertentu. Pembentukan sikap dipengaruhi oleh beberapa faktor yakni pengalaman pribadi, kebudayaan, orang lain yang dianggap penting, media masa, lembaga pendidikan dan lembaga agama, dan faktor emosional. Berdasarkan paparan tersebut maka pendidikan sangat penting untuk membentuk sikap positif terhadap minimisasi sampah sehingga diharapkan dapat meningkatkan perilaku pengelolaan sampah.

\section{KESIMPULAN}

1. Lebih dari separoh $(56,1 \%)$ masyarakat memiliki tingkat pengetahuan yang kurang baik dalam mengelola sampah di RW 8 RT 02 Kelurahan Kurao Pagang Kecamatan Nanggalo Padang Tahun 2018.

2. Lebih dari separoh $(53,7 \%)$ masyarakat memiliki sikap yang negatif dalam mengelola sampah di RW 8 RT 02 Kelurahan Kurao Pagang Kecamatan Nanggalo Padang Tahun 2018.

3. Lebih dari separoh $(56,1 \%)$ masyarakat memiliki perilaku yang tidak baik dalam mengelola sampah di RW 8 RT 02 Kelurahan Kurao Pagang Kecamatan Nanggalo Padang Tahun 2018.

4. Terdapat hubungan tingkat pengetahuan dengan perilaku masyarakat dalam

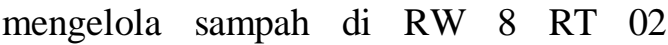

Kelurahan Kurao Pagang Kecamatan Nanggalo Padang tahun 2018.

5. Terdapat hubungan sikap dengan perilaku masyarakat dalam mengelola sampah di RW 8 RT 02 Kelurahan Kurao Pagang Kecamatan Nanggalo Padang tahun 2018.

\section{SARAN}

1. Bagi Dinas Kesehatan

Diharapkan bagi Dinas Kesehatan agar melakukan upaya untuk meningkatkan pengetahuan dan sikap masyarakat dalam mengelola sampah dengan melakukan penyuluhan melalui cara menyebarkan selebaran, leaflet dan berbagai media tentang cara mengelola sampah yang baik.

2. Dinas kebersihan dan pertamanan

Agar dapat menambah sarana dan prasarana penampungan sampah dan selalu memantau petugas kebersihan dan mengangkut sampah ke tempat pembuangan sampah secara rutin dan tepat waktu.

\section{DAFTAR PUSTAKA}

Arikunto. 2006. Prosedur Penelitian Suatu Pendekatan Praktik. Jakarta : Rineka Cipta

Budiman.2006. Pengantar Kesehatan Lingkungan. Jakarta : Penerbit Buku Kedokteran EGC.

Budiman. 2013. Kapita Selekta Kuesioner Pengetahuan dan Sikap dalam Penelitian Kesehatan. Jakarta : Salemba Medika.

Budiman. 2013. Kapita Selekta Pengetahuan dan Sikap dalam Penelitian Kesehatan. Jakarta : Salemba Medika.

Dinas Lingkungan Hidup Sumatera Barat. 2017.Laporan akhir Dokumen Lingkungan Biotik-Abiotik Karst Propinsi Sumatera Barat.

Dinas Kebersihan dan Pertamanan Kota Padang. 2014. Master Plan Pengelolaan SampahKota. Padang : DKK 
Dinas Kesehatan Kota Padang.2017.Profil Kesehatan Kota Padang tahun 2017. Padang : DKK.

Indang. 2017. Sukses Mengolah Sampah Organik Menjadi Pupuk Organik. Yogyakarta: Pustaka Baru Press.

Kemenkes RI. 2010. Profil Kesehatan Indonesia. Jakarta : Kemenkes RI

Marojahan.2015. Hubungan pengetahuan masyarakat tentang sampah dengan perilaku mengelola sampah rumah tangga. Jurnal PenelitianFakultas Kesehatan Masyarakat.Jakarta : Universitas Indonesia

Mulasari.2012. Hubungan tingkat pengetahuan dan sikap terhadap perilaku masyarakat dalam mengolah sampah di Yogyakarta. Jurnal Penelitian Fakultas Kesehatan Masyarakat. Yogyakarta : Universitas Gajah Mada

Notoatmodjo, S. 2011. Kesehatan Masyarakat Ilmu dan Seni Edisi Revisi. Jakarta:Rineka Cipta.

Notoatmodjo, S. 2010. Metodologi Penelitian Kesehatan. Jakarta : Rineka Cipta.

Notoatmodjo, S. 2005. Promosi Kesehatan Teori dan Aplikasi. Jakarta : Rineka Cipta.

Notoatmodjo, S. 2003. Pendidikan Kesehatan dan Ilmu Perilaku. Jakarta : Rineka Cipta.

Pemko Padang. 2014. Keputusan Walikota Nomor 550 tahun 2014 tentang kawasan bebas sampah. Padang : Pemko

Purwendro \& Nurhidayat. 2006. Kompos. Jakarta : Penebar Swadaya

Rohmatin. 2016. Hubungan antara pengetahuan dan sikap dengan pengelolaan sampah rumah tangga di lingkungan II Kelurahan Sumompo Kecamatan
Tuminting Kota Manado. Jurnal Penelitian. Manado : Universitas Sam Ratulangi

Sumantri,Arif. 2010. Kesehatan Lingkungan Edisi Revisi. Jakarta. PT. Fajar Interpratama Mandiri.

Saputra.2017. Pengetahuan, Sikap, dan Perilaku Pengelolaan Sampah pada Karyawan di Kampus. Jurnal PenelitianFakultas Kesehatan Masyarakat. Jakarta : Universitas Indonesia.

Sepdianti.2016. Perilaku masyarakat dalam pengelolaan sampah di Kelurahan Gunung Batu, Kecamatan Bogor Barat. Jurnal PenelitianFakultas Kesehatan Masyarakat. Jakarta : Universitas Indonesia.

Soemirat. 2004. Kesehatan Lingkungan, Yogyakarta : Gadjah mada University press.

Slamet. 2012. Sampah dan dampak yang terhadap kesehatan. http://agusslamet.staf.narotama.ac.id/20 $\underline{12 / 02 / 07 / \text { hello-world }}$

Statistik PersampahanDomestik Indonesia tahun 2015.

Sudradjat. 2007.Mengelola Sampah Kota. Jakarta : Penebar Swadaya

Sumantri. 2010.Kesehatan Lingkungan. Jakarta: Kencana Prenada Media Group 